\title{
Encouraging Collaborative Governance in Badan Usaha Milik Desa (BUM Desa) Management in Indonesia
}

\author{
Chandra Wijaya ${ }^{1 *}$, Vicky Dian Pratama Sari ${ }^{2}$ \\ Magister Administrasi dan Kebijakan Publik, Fakultas Ilmu Administrasi \\ Univeristas Indonesia \\ Email:wijayachandra@yahoo.com¹․ vickydianpratamasari@gmail.com
}

(Received: May 16-2019; revised: Juny 15-2019; published: December 31-2019)

\begin{abstract}
This essay tries to explore and develop a collaborative governance concept as an alternative approach for developing BUM Desa program of the Ministry of Village, Development Regions and Transmigration. Recently, there are more than 45,000 units of BUM Desa in which 66\% of them were established after 2015. However, the vast majority of them are still under-developed. This study uses a qualitative evaluation method for a deeper and more detailed understanding the dynamics of an ongoing program. Data collection techniques used in this study are in-depth interview, Focus Group Discussion (FGD), observation, documentary, visual material and online data gathering with constant comparative analysis. The result from this study explain that 'BUM Desa Bersama Program' is an example of a collaborative governance concept. 'BUM Desa Bersama' is a collaboration between village's economic institutions involving several BUM Desa's across villages. The government needs to encourage broader partnerships to enable experiences exchange which may strengthen the BUM Desa and expand their business scale and market penetration. This partnerships may involve collaboration with public institutions and private institutions.
\end{abstract}

Keywords: BUM Desa; Collaborative governance; BUM Desa Bersama; Public institution; and private institution.

\section{INTRODUCTION}

Equitable development of rural areas is an implementation of the government's prioritized agenda in an effort of developing Indonesia from peripheral territories by strengthening villages as development base (Farida, 2017; Morss, 2019; Salim \& Negara, 2018; Tolkach \& King, 2015; Wicaksono, 2018). The development gap in rural areas is a homework for the government to solve. Based on data from Badan Pusat Statistik (BPS) released in January 2017, there were inequalities and prosperity gap between rural and urban areas from 1993 to 2016. The percentage of poverty in rural areas was greater than urban areas. It reached $13.96 \%$ in rural areas and 7.73\% in urban areas in 2016 (Irawan, 2017). While the latest data (2018) explains poverty in rural areas was $13.10 \%$ and $6.89 \%$ in urban areas. This figure shows inequality of economic development between rural and urban areas. Therefore, rural regional development is an absolute necessity and a serious concern to be prioritized in order to decrease poverty, especially in rural areas. 
226 Jurnal Ilmiah Ilmu Administrasi Publik: Jurnal Pemikiran dan Penelitian Administrasi Publik

Volume 9 Number 2,July - December 2019. Page 225-236

Table 1

Village categories in Indeks Desa Membangun (IDM)

\begin{tabular}{|lcc|}
\multicolumn{1}{c}{ Categories } & Amount & Percentage \\
\hline Desa Sangat Tertinggal & 14,107 & $18.87 \%$ \\
\hline Desa Tertinggal & 33,948 & $45.41 \%$ \\
\hline Desa Berkembang & 22,916 & $30.66 \%$ \\
\hline Desa Mandiri & 173 & $0.23 \%$ \\
\hline Desa Maju & 3,610 & $4.83 \%$ \\
\hline
\end{tabular}

Source : Ministry of Village, Development Regions and Transmigration (2016)

Based on these facts, the national development strategy must be sought by giving the village economic development a larger portion. Basically villages have a lot of potentials that can be driven to encourage economic development. Villages can be the main force of national development by mobilizing their economic potentials as development base. This effort can be a practical solution in advancing the national economy through rural areas development (Sumodiningrat \& Wulandari, 2016).

Attention to the mainstreaming of village economic development has the best momentum with the birth of Undang-undang Desa Tahun 2014 (UU Desa). It was a milestone in the village development. UU Desa provides a special space by recognizing of village's authority. Irawan (2017) explains the special space is provided by the principle of recognition and subsidiarity. Recognition principle is recognizing the village existence with all of its rights of origin including recognition of its tradition. While the subsidiarity principle refers to respecting village's authority in accordance with the origin of tradition. Through these two principles, village has local authority and rights of origin authority that can be used to determine their fate and future independently (Moreda, 2017; Murtazashvili \& Murtazashvili, 2016). These privileges are expected to encourage village development massively, equitably and sustainably.

The problem of village economic inequalities and the birth of UU Desa momentum became important capital in determining government policy direction. Within this framework, government launched the development program of Badan Usaha Milik Desa (BUM Desa) as a solution to overcome rural economic problems and encourage village community participation in achieving their welfare. BUM Desa is projected to be a pillar of village economy which function as a commercial institution in generating economic benefits and at the same time as a social institution to overcome various socio-economic problems. The existence of BUM Desa gives wide opportunity to open village access and economic assets to increase participation, employment opportunities, and village economy (Rhodes \& Nabi, 1992; Rozelle \& Boisvert, 1995; Tomich, Kilby, \& Johnston, 2018; VanStone, 1960). BUM Desa existence is expected to encourage advance changes in village economy for the prosperity of the village community.

In conjure with the expectation, BUM Desa rapidly accommodated by villages across Indonesia. Thousands of villages established their own BUM Desa and keep increasing year by 
year. In 2014, the number of registered BUM Desa reached 1.022 units. Meanwhile by the end of 2018, this number increased to 45.549 units all across Indonesia. On the other hand, there's this question about how this number directly affected the economic growth in those villages. In reality, $B U M$ Desa did not have a simultaneous effect to the economic growth of their respective villages. According to a study by Pusat Penelitian dan Pengembangan (Puslitbang), Ministry of Village, Development Regions and Transmigration (2018) who conducted survey on BUM Desa Development Indocators in a number of villages in Java shows that majority of registered BUM Desa still only categorized as "BUM Desa Bentukan" where there economic contribution are below 50 percent. Furthermore, 52.86 percent of these BUM Desa are under developed with annual gross income under 10 million rupiahs. It means, the business and economic contribution of the majority of BUM Desa are still very limited.

This reality reflects the conditions of BUM Desa program in Indonesia which requires system improvement and better management. These improvements will affect BUM Desa management program, so these BUM Desa will have quality to match their large quantities and have more substantial impact for the development of the village. Considering the government limitations, it is necessary to build a collaborative system for cross-sectoral cooperative relationships. Moreover, BUM Desa Development Program weaknesses can be addressed through collaborative governance methods which connect the government with various private sectors institutions to support program achievement.

Collaborative governance is a concept that describes a process involving various stakeholders based on their individual interests which aim to achieve the common goals and intentions (Bodin, Sandström, \& Crona, 2017; Shilbury \& Ferkins, 2015). While according to Ansell \& Gash (2007) collaborative governance is an arrangement that regulates one or more public institutions directly involved with private stakeholders in a formal collective decisionmaking process, consensus-oriented, and discussion aimed for making or implementing public policies or managing programs or public assets (Mintrom \& Luetjens, 2017). In addition, that collaborative governance as a collective and egalitarian process, has equal opportunity and substantive authority by each participant and in the decision of making process (Bodin, 2017; Bodin et al., 2016; Emerson \& Nabatchi, 2015).

One of the collaborative governance form is Public Private Partnership (PPP). This concept emphasizes the aspect of cooperation or partnership to unite government and private interests. The main assumption is the limited ownership by each stakeholder are expected to bridge various interests to achieve the common goals. World Bank (2014) describes Public Private Partnership as long-term contract between private sector and government agency to provide a public asset or service. According to the contract, the private sector will be shouldering significant risks and management responsibilities with remuneration determined based on performance. Daraba, Akib, Saggaf, Cahaya, \& Salam (2018); Mappasere, Imbaruddin, \& Akib (2014); Syam, Lamangida, Madubun, \& Akib (2018) concludes that public and private partnerships are collaborations based on agreements in order to produce a public service product with risk sharing, resources accumulation, and common goals.

The process should unify various interests, resources, and risk sharing to achieve common goals. Following this, it requires a thorough understanding of the of the policy aspects to be implemented. The collaborative governance concept serves as instrument to dissect a solution framework of BUM Desa development in Indonesia and formulates alternative 
228 Jurnal Ilmiah Ilmu Administrasi Publik: Jurnal Pemikiran dan Penelitian Administrasi Publik

Volume 9 Number 2,July - December 2019. Page 225-236

perspectives. This concept is considered relevant to examine the phenomenon of BUM Desa which currently is in a growing process. BUM Desa Bersama program which is being developed by the government is closely related to collaborative governance concept, so it may form a deep and comprehensive collaboration.

\section{METHOD}

This essay is a result of research conducted at the Ministry of Village, Development Regions and Transmigration and focusing on the evaluation of BUM Desa development in Indonesia. This study uses qualitative evaluation method (Creswell \& Poth, 2018). Patton (2006) explains this approach describes in depth and detail for understanding the dynamics of running program. The evaluation process requires detailed descriptions of the running program based on observation and interview. An important source of qualitative evaluation data is direct observation. This method emphasizes the process as a focus in evaluation by looking at how the results or outcomes are produced. Thus, the evaluation process will develop, be descriptive, continuous, flexible and inductive. Qualitative evaluation presents more detailed information of program activities, processes and participants.

The basis for determining informants uses two ways: purposive procedures and snowball procedures with in-depth interviews, Focus Group Discussions, observation, documentaries, visual or photographic materials and online data accumulation as data collection techniques. In addition to that, this study uses constant comparative analysis. The essence of this technique is used to compare events that occurred when researcher analyzed these events and conducted perform continuously during the study (Bungin, 2007).

\section{RESULT AND DISCUSSION}

Badan Usaha Milik Desa (BUM Des) program is the main focal point for economic development. BUM Desa is an institution reflecting the village government and community partnership which truly managed at village level. BUM Desa performs various form of productive activities aimed for the prosperity of the community. BUM Desa may conduct its business from the village own capitals, its natural resources, and other potential resources available. BUM Desa may conduct various business and services appropriate to the existing rules (Setyobakti, 2017; Winarsi, Widyantoro, \& Moechthar, 2018).

BUM Desa are to be managed by developing its main business or diversification of business units, and sale expansion of its products or services. The types of business it may develop are Social Business, Renting, Brokering, Production, Trading, Finance, and may form a Holding business. These various businesses must be compatible with natural resources and local potencies available. The main principal is to promote a business based on local potencies by utilize available resources as wide as possible for village's prosperity. 
Table 2

\begin{tabular}{|c|c|c|c|c|c|c|c|c|c|}
\hline \multicolumn{10}{|c|}{ Distribution of BUM Dess per Province } \\
\hline Sumatera & Total & Kalimantan & Total & $\begin{array}{c}\text { Java \& } \\
\text { Nusa } \\
\text { Tenggara }\end{array}$ & Total & Sulawesi & Total & $\begin{array}{c}\text { Maluku } \\
\text { and } \\
\text { Papua }\end{array}$ & Total \\
\hline Aceh & 6471 & $\begin{array}{l}\text { West } \\
\text { Kalimantan }\end{array}$ & 509 & West Java & 3816 & $\begin{array}{l}\text { West } \\
\text { Sulawesi }\end{array}$ & 531 & Maluku & 715 \\
\hline $\begin{array}{l}\text { Sumatra } \\
\text { utara }\end{array}$ & 2130 & $\begin{array}{l}\text { East } \\
\text { Kalimantan }\end{array}$ & 795 & Banten & 587 & Gorontalo & 647 & $\begin{array}{l}\text { North } \\
\text { Maluku }\end{array}$ & 425 \\
\hline $\begin{array}{l}\text { Riau } \\
\text { islands }\end{array}$ & 101 & $\begin{array}{l}\text { South } \\
\text { Kalimantan }\end{array}$ & 1203 & Bali & 587 & $\begin{array}{l}\text { South } \\
\text { Sulawesi }\end{array}$ & 1931 & Papua & 598 \\
\hline Riau & 1013 & $\begin{array}{l}\text { North } \\
\text { Kalimantan }\end{array}$ & 210 & $\begin{array}{l}\text { Yogyakarta } \\
\text { Special } \\
\text { Region }\end{array}$ & 291 & $\begin{array}{l}\text { Southeast } \\
\text { Sulawesi }\end{array}$ & 1729 & $\begin{array}{l}\text { West } \\
\text { Papua }\end{array}$ & 132 \\
\hline $\begin{array}{l}\text { West } \\
\text { Sumatra }\end{array}$ & 676 & $\begin{array}{l}\text { Central } \\
\text { Kalimantan }\end{array}$ & 846 & $\begin{array}{l}\text { Central } \\
\text { Java }\end{array}$ & 3057 & $\begin{array}{l}\text { North } \\
\text { Sulawesi }\end{array}$ & 903 & & \\
\hline Jambi & 911 & & & East Java & 5865 & $\begin{array}{l}\text { Central } \\
\text { Sulawesi }\end{array}$ & 1357 & & \\
\hline $\begin{array}{l}\text { South } \\
\text { Sumatra }\end{array}$ & 2338 & & & NTB & 881 & & & & \\
\hline
\end{tabular}

\section{BUM Desa Distribution by Province}


230 Jurnal Ilmiah Ilmu Administrasi Publik: Jurnal Pemikiran dan Penelitian Administrasi Publik Volume 9 Number 2,July - December 2019. Page 225-236

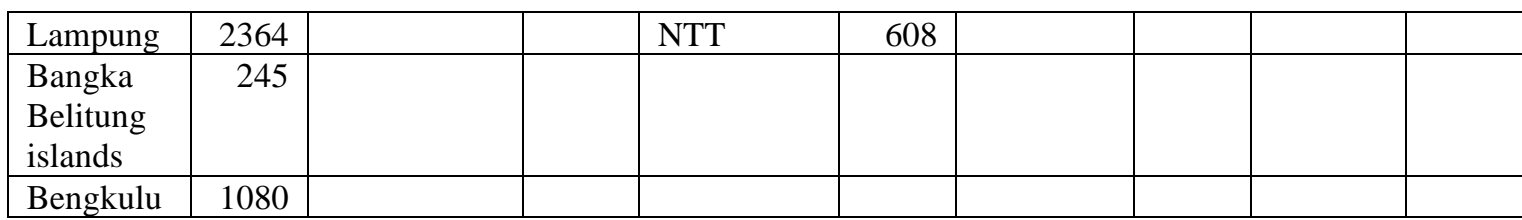

Source : Ministry of Village, Development Regions and Transmigration (2018)

BUM Desa expected to serve as pulling factor for village's economic growth. BUM Desa program is the main program between other prioritized government programs. Its existence is expected to provide domino effect to open participation, access, and economic asset for villages communities. Thus, village's economic development process could be developed independently by the utilization of natural resources and other potencies.

Since its inception, BUM Desa has been growing rapidly. Thousands of villages have established their own BUM Desa, and the number has been increasing year by year. In 2014, the number of BUM Desa registered is 1,022 units, and increased to 11,945 in 2015. This increase was in parallel with Dana Desa reorientation and reformulation which intensively advocating BUM Desa as its prioritized program. In 2016, the number of BUM Desa increased to 18,446 units, and by 2017 BUM Desa program found momentum as it was inaugurated as prioritized program for Dana Desa. BUM Desa number keep increasing to 39,149 units by the end of 2017 and this number reached 45,549 units by the end of 2018 .

Table 3

The existence of $B U M$ Desa by Year

\begin{tabular}{|c|c|c|c|c|c|c|c|c|}
\hline \multirow{2}{*}{$\begin{array}{c}\text { The existence of BUM } \\
\text { Desa }\end{array}$} & \multicolumn{8}{|c|}{ Region } \\
\hline & 1 & 2 & 3 & 4 & 5 & 6 & 7 & $\begin{array}{l}\text { National } \\
\text { Average }\end{array}$ \\
\hline \multicolumn{9}{|c|}{ A. There is no BUM Desa yet } \\
\hline $\begin{array}{l}\text { BUM Desa has never } \\
\text { been established / has } \\
\text { been dispersed }\end{array}$ & 4,1 & 24,6 & 0,0 & 53,1 & 0,0 & 20,0 & 92,9 & 24,3 \\
\hline \multicolumn{9}{|l|}{ B. There is BUM Desa } \\
\hline $\begin{array}{l}\text { 1. BUM Desa was } \\
\text { established before } \\
2015\end{array}$ & 8,2 & 11,5 & 22,2 & 3,1 & 12,5 & 5,0 & 0,0 & 9,0 \\
\hline $\begin{array}{l}\text { 2. BUM Desa was } \\
\text { established after } 2015\end{array}$ & 87,8 & 63,9 & 77,8 & 43,8 & 87,5 & 75,0 & 7,1 & 66,7 \\
\hline
\end{tabular}

Note : Region 1.Sumatera, 2.Jawa, 3.Nusa Tenggara, 4.Kalimantan, 5.Sulawesi, 6.Maluku, 7.Papua 
Source : Ministry of Village, Development Regions and Transmigration (2018)

From Table 3 above, BUM Desa rise to prominent found its momentum since 2015. After the implementation of UU Desa and supported by Dana Desa, BUM Desa program gained more serious attentions. Nationally, BUM Desa established prior to 2015 only amount to $9 \%$ of the total number of BUM Desa currently existing. Further, in each main island, the amount are as follows: Sumatera is $8.2 \%$, Java $11.5 \%$, Nusa Tenggara $53.1 \%$, Sulawesi $0 \%$, Maluku $20 \%$, and Papua at $92.9 \%$.

Meanwhile, BUM Desa established after 2015 nationally accounted for $66.7 \%$. For each of main islands: Sumatera has $87.7 \%$, Java $63.9 \%$, Nusa Tenggara $77.8 \%$, Kalimantan $43.8 \%$, Sulawesi $87.5 \%$, Maluku 75\%, and Papua at 7.1\%. The amount of BUM Desa not yet established and/or stopped its operation amount to 24.3\% nationally. By islands the number are: Sumatera 4.1\%, Java 24.6\%, Nusa Tenggara 0\%, Kalimantan 53,1\%, Sulawesi 0\%, Maluku $20 \%$, and Papua at $92,9 \%$.

This data shows positive reception and enthusiasm from the community related to the establishment of BUM Desa. Some regions such as Sulawesi and NTT have 0\% of villages did not have a BUM Desa established. The massive number of BUM Desa established could serve as important capital and play important part as economic development instrument in their respective villages. By quantity, the existence of BUM Desa has a very promising potential to develop further. But a deeper assessment needs to be conducted to better understand how it influence and push economic growth of the community and village. Furthermore, BUM Desa is vulnerable to complicated procedure which heavily prioritize on administrational processes rather than substantial ones.

Evaluation of BUM Desa development is an important and integral step to optimize and increase its productivity and quality. The evaluation should not focus only on profit and loss, but more on how the management of BUM Desa being conducted and improved with monitoring and supervising, mainly for new established BUM Desa. If this process is neglected, the saying "withered before bloom" will in turn become an acute disease in the effort of BUM Desa development in Indonesia. Henceforth, research on BUM Desa development is an absolute necessity so the program orientation and policy intervention by government will solve the urgent and important weaknesses.

Research conducted by Ministry of Village, Development Regions and Transmigration (KDPDTT) on BUM Desa development indicators found interesting facts on how BUM Desa took part in economic empowerment. Indikator Perkembangan (IP) BUM Desa is a measurement to evaluate the success and development of BUM Desa by assessing a number of indicators such as social dimension, economical dimension, management dimension, and environmental dimension. These four dimensions are derivatives of the BUM Desa establishment goals as stated in Ministry of Village, Development Regions and Transmigration in which grouped into three categories: BUM Des Bentukan, BUM Desa Berkembang, and BUM Des Desa Maju.

Research conducted by Ministry of Village, Development Regions and Transmigration (KDPDTT (2018) explain research result on the forming process of the Indikator Perkembangan (IP) BUM Desa which conducted in Java, with samples from various regions such as: BUM Desa in Bantul Regency represent BUM Desa Maju, Wonogiri Regency represent a region with 
232 |Jurnal Ilmiah Ilmu Administrasi Publik: Jurnal Pemikiran dan Penelitian Administrasi Publik Volume 9 Number 2,July - December 2019. Page 225-236

less developed access and natural barriers, and Bekasi Regency represent industrial region. This research exercised that $77.33 \%$ of BUM Desa are fall under BUM Desa Bentukan category, $21.33 \%$ fall under BUM Desa Berkembangcategory, and 1,33\% fall under BUM Desa Maju resepectively. Meanwhile, assessment from economic contribution, management, and social aspect shows under 50\%, and environmental aspect show 58\%. These conditions argue that majority of the BUM Desa were still under-developed and were not yet contribute significantly on their village economic growth.

Some factors causing the rather slow development of BUM Desa are the unavailability of training and supervising for the new established BUM Desa, the birth of elit capute where BUM Desa dominated by the elites from local government, limited accesses to capital, limited knowledge, and the lack of managerial prowess. These conditions must be seen as critical notes in the myriad of information about the success of BUM Desa program.

\section{BUM Desa Acceleration Program: Encouraging Collaborative Governance through ' $B U M$ Desa Bersama'}

The problem of stunted growth of BUM Desa Development must be addressed as a common concern. As many as $66.7 \%$ of BUM Desa have only been formed after 2015 , which means that it is still too early to be allowed to develop independently without intervention by the government and related institutions. The huge potential of BUM Desa could be an important capital for the government to drive wide and massive economic growth. In order to encourage acceleration and penetration of BUM Desa program, government needs to encourage BUM Desa collaboration through development of BUM Desa Bersama Program. This program are becoming a progressive step for government to develop BUM Desa, encouraging partnership between BUM Desa and government or other stakeholder for collective and rapid growth.

\section{Table 4}

\section{Institutionalization Aspects of BUM Desa and BUM Desa Bersama}

\begin{tabular}{|l|l|l|}
\hline $\begin{array}{l}\text { Institutionalization } \\
\text { Aspect }\end{array}$ & $\begin{array}{l}\text { Village-owned } \\
\text { Enterprise } \\
\text { (BUM Desa) }\end{array}$ & $\begin{array}{l}\text { Joint Village-owned Enterprise } \\
\text { (BUM Desa Bersama) }\end{array}$ \\
\hline Legal Basis & $\begin{array}{l}\text { Juridical norms about } \\
\text { institutionalizing BUM } \\
\text { Desa (articles 87-90 of } \\
\text { the Village Law) }\end{array}$ & $\begin{array}{l}\text { 1). juridical norms about institutional } \\
\text { BUm Desa (vide articles 87-90 of the } \\
\text { Village Law). (2) social foundation: } \\
\text { Cooperation between villages, inter- } \\
\text { village business services, BUM desa } \\
\text { owned by 2 villages or more (vide article } \\
\text { 92 paragraph 6 of the Village Law. 3) } \\
\text { locus of inter-village business } \\
\text { development positions: rural areas (vide } \\
\text { articles 83-85 Law Village) }\end{array}$ \\
\hline
\end{tabular}




\begin{tabular}{|l|l|l|}
\hline & $\begin{array}{l}\text { BUM Desa-scale local } \\
\text { technical-institutional } \\
\text { arrangements Village } \\
\text { (vide article 132-140 } \\
\text { PP no 43/2014 jo. PP } \\
\text { No. 47/2015 }\end{array}$ & $\begin{array}{l}\text { Special arrangements for BUM Desa } \\
\text { Bersama (Establishment, merging, } \\
\text { smelting BUM Desa) Vide article 141 PP } \\
\text { No 43/2014 jo. PP No. 47/2015. } \\
\text { Institutional technical arrangements by } \\
\text { following the legal substance in the BUM } \\
\text { Desa institution at the local scale of the } \\
\text { Village }\end{array}$ \\
\hline Paradigm & $\begin{array}{l}\text { Village building } \\
\text { Builld a village } \\
\text { Location Basis } \\
\text { pulse of the efforts of } \\
\text { the village community }\end{array}$ & $\begin{array}{l}\text { villages that agreed to cooperate between } \\
\text { villages }\end{array}$ \\
\hline village meeting & $\begin{array}{l}\text { inter-village discussion or other } \\
\text { designation }\end{array}$ \\
\hline
\end{tabular}

Source : Ministry of Village, Development Regions and Transmigration (2016)

BUM Desa Bersama Program is based on a PP No. 43 of 2014 article 141 which states (1) In the framework of cooperation between villages, 2 (two) villages or more can form BUM Desa Bersama. (2) Establishment of BUM Desa as referred to in paragraph (1) can be done through the establishment, merger, or consolidation of BUM Desa. (3) Establishment, merger or fusion of BUM Desa as referred to in paragraph (1) and paragraph (2) and management of BUM Desa are carried out in accordance with the provisions of the legislation. Thus, the regulation forms the basis for the birth of BUM Desa Bersama program. Until 2018, 64 units of BUM Desa Bersama have been formed in 48 Regencies spread across 16 Provinces. BUM Desa Bersama has 336 managers and produces 185 types of flagship products.

BUM Desa Bersama is a collaboration of village economic institutions involving BUM Desa across different villages. BUM Desa Bersama can be a place to unite while providing protection to small economic actors to be able to develop more rapidly without having to comply with available local potential. The government need to encourage business entities to form partnerships or collaborations between BUM Desa, BUM Desa and Private, or BUM Desa with civil groups. Partnerships are important for exchanging information and knowledge and strengthening financial, managerial and digital marketing, so that the business opportunities and market penetration will be broader. This can be fulfilled with efforts to build synergy and collaboration with private elements.

In the context of collaborative governance, thousands of BUM Desa currently in still establishing process should be encouraged to form partnerships, either through the BUM Desa Bersama program or independently cooperating with private agencies. The various limitations of BUM Desa such as management, assistance, access to capital and knowledge can be fulfilled by mechanism of cooperation or partnership. Various efforts can be made as follows:

1. BUM Desa can expand its cooperation by synergizing with public institutions such as the Regional Government, related agencies, or SOEs to support the BUM Desa development program. For example, BUMDes that are engaged in tourism can cooperate with the 
234| Jurnal Ilmiah Ilmu Administrasi Publik: Jurnal Pemikiran dan Penelitian Administrasi Publik Volume 9 Number 2,July - December 2019. Page 225-236

Department of Tourism, BUMD / BUMN to provide assistance and training to increase the management capacity of BUM Desa.

2. Cooperation between BUM Desa can be done with private institutions, especially in the field of market place or modern market to help promoting the results of BUM Desa products. Cooperation can also be carried out through civil institutions or NGOs to provide assistance and training.

3. Collaboration between BUM Desa can also formed between BUM Desa which are still in the category of BUM Formed Villages and BUM Desa Berkembang with BUM Desa in more advanced categories. Synergy between BUM Desa with large turnover and that BUM Desa with no turnover yet. This is important thing o do, so that the less developed BUM Desa has best practice examples to follow in developing their business.

\section{CONCLUSION}

Encouraging collaborative governance can be an alternative in BUM Desa development program in Indonesia. BUM Desa Bersama program which is currently being developed by the government must be sought as a mean to gain a wider range. These days the program has created 64 units of BUM Desa Bersama. BUM Desa has great potential and is still wide open oppotunity. The number of BUM Desa continues to increase from time to time. In the future, BUM Desa Bersama program needs to get a bigger attention so the majority of BUM Desa which are still in a development proces could also form partnerships and cooperations. Partnership and cooperation can formed with developed BUM Desa as well as other public and private institutions. Thus, the still developing BUM Desa can overcome their limitation by receiving assistance, training, and capital access assistance.

Implementation of collaborative governance in BUM Desa programs will certainly be able to elevate and encourage a leap for BUM Desa to develop collectively. In addition to relying on collaborative programs, the government needs to seek other intervention programs specify to further enhance newly established or developing BUM Desa. Hence, all of BUM Desa in Indonesia can progress hand in hand to develop economic centers in their village which can have a big positive impact on the economy of rural communities.

\section{REFERENCES}

Ansell, C., \& Gash, A. (2007). Collaborative Governance in Theory and Practice Journal of Public Administration Research and Theory Advance Access published November 13.

Bodin, Ö. (2017). Collaborative environmental governance: achieving collective action in social-ecological systems. Science, 357(6352), eaan1114.

Bodin, Ö., Robins, G., McAllister, R., Guerrero, A., Crona, B., Tengö, M., \& Lubell, M. (2016). Theorizing benefits and constraints in collaborative environmental governance: a transdisciplinary social-ecological network approach for empirical investigations. Ecology and Society, 21(1). 
Bodin, Ö., Sandström, A., \& Crona, B. (2017). Collaborative networks for effective ecosystem-based management: A set of working hypotheses. Policy Studies Journal, 45(2), 289-314.

Bungin, B. (2007). Penelitian kualitatif: komunikasi, ekonomi, kebijakan publik, dan ilmu sosial lainnya. Kencana.

Creswell, J. W., \& Poth, C. N. (2018). Qualitative inquiry Research Design Choosing Among Five Approaches (Vol. 53). https://doi.org/10.1017/CBO9781107415324.004

Daraba, D., Akib, H., Saggaf, M. S., Cahaya, A., \& Salam, R. (2018). Basic Public Service Partnership Model Based on Gender Perspective in Makassar City, Indonesia. Journal of Legal, Ethical and Regulatory Issues.

Emerson, K., \& Nabatchi, T. (2015). Collaborative governance regimes. Georgetown University Press.

Farida, U. (2017). Analysis of Empowerment Program that was Implemented in Mamuju Regency East Sulawesi Indonesia. 149(Icest), 19-21.

Mappasere, F., Imbaruddin, A., \& Akib, H. (2014). PUBLIC PRIVATE AND COMMUNITY PARTNERSHIP IN WASTE MANAGEMENT SERVICES IN KARANG ANYAR DISTRICT OF MAKASSAR CITY. International Journal of Academic Research, 6(4).

Mintrom, M., \& Luetjens, J. (2017). Creating public value: Tightening connections between policy design and public management. Policy Studies Journal, 45(1), 170-190.

Moreda, T. (2017). Large-scale land acquisitions, state authority and indigenous local communities: insights from Ethiopia. Third World Quarterly, 38(3), 698-716.

Morss, E. R. (2019). Implementing rural development projects: Lessons from AID and World Bank Experiences. Routledge.

Murtazashvili, I., \& Murtazashvili, J. (2016). The origins of private property rights: states or customary organizations? Journal of Institutional Economics, 12(1), 105-128.

Patton, R. (2006). Software testing. Pearson Education India.

Rhodes, C., \& Nabi, N. (1992). A village economy in the shadow of the city? Global Finance and Urban Living: A Study of Metropolitan Change, 334.

Rozelle, S., \& Boisvert, R. N. (1995). Control in a dynamic village economy: The reforms and unbalanced development in China's rural economy. Journal of Development Economics, 46(2), 233-252.

Salim, W., \& Negara, S. D. (2018). Infrastructure Development under the Jokowi Administration: Progress, Challenges and Policies. Journal of Southeast Asian Economies, 35(3), 386-401.

Setyobakti, M. H. (2017). Identification of Business Enterprises Bumdes Based on Social and Economic Aspect. Jurnal Ilmiah Bidang Akuntansi Dan Manajemen (JEMA), 14(2).

Shilbury, D., \& Ferkins, L. (2015). Exploring the utility of collaborative governance in a 
236 Jurnal Ilmiah Ilmu Administrasi Publik: Jurnal Pemikiran dan Penelitian Administrasi Publik Volume 9 Number 2,July - December 2019. Page 225-236

national sport organization. Journal of sport management, 29(4), 380-397.

Sumodiningrat, G., \& Wulandari, A. (2016). Membangun Indonesia dari desa. Media Pressindo.

Syam, H., Lamangida, T., Madubun, J., \& Akib, H. (2018). Public Entrepreneurship Perspective In Management Of The Limboto Lake In Gorontalo Regency, Indonesia. Academy of Entrepreneurship Journal, 24(4), 1-10.

Tolkach, D., \& King, B. (2015). Strengthening community-based tourism in a new resourcebased island nation: Why and how? Tourism Management, 48, 386-398.

Tomich, T. P., Kilby, P., \& Johnston, B. F. (2018). Transforming agrarian economies: Opportunities seized, opportunities missed. Cornell University Press.

VanStone, J. W. (1960). A successful combination of subsistence and wage economies on the village level. Economic Development and Cultural Change, 8(2), 174-191.

Wicaksono, D. (2018). The development of rural area residence based on participatory planning case study: A rural residential area of Pucungrejo village, Magelang through "neighborhood development" program. AIP Conference Proceedings, 1941(1), 20033. AIP Publishing.

Winarsi, S., Widyantoro, A., \& Moechthar, O. (2018). The Law Principles for Village-Owned Enterprises (BUMDes) Managementin Indonesia to Improve the Village's Economy. Sociological Jurisprudence Journal, 1(2), 130-136. 